\title{
Evaluation of physiological and biochemical responses in different seasons in Surti buffaloes
}

\author{
Sandhya S. Chaudhary ${ }^{1}$, Virendra Kumar Singh ${ }^{1}$, Ramesh C. Upadhyay ${ }^{2}$, Gopal Puri ${ }^{1}$, Arjun B. Odedara ${ }^{1}$ and \\ Pankaj A. Patel ${ }^{1}$
}

1. Department of Veterinary Physiology and Biochemistry, Vanbandhu College of Veterinary Science and Animal Husbandry, Navsari Agricultural Univesrity, Navsari - 396 450, Gujarat, India; 2. Division of Dairy Cattle Physiology, National Dairy Research Institute, Karnal - 132 001, Haryana, India.

Corresponding author: Sandhya S. Chaudhary, e-mail: sandhyachaudhary6@gmail.com, VKS: drvksingh1981@

gmail.com, RCU: upadhyay.ramesh@gmail.com, GP: drgopalpuri@gmail.com, ABO: arjunodedra81@gmail.com, PAP: gamitpankaj09@gmail.com

Received: 20-01-2015, Revised: 30-04-2015, Accepted: 05-05-2015, Published online: 17-06-2015

doi: 10.14202/vetworld.2015.727-731 How to cite this article: Chaudhary SS, Singh VK, Upadhyay RC, Puri G, Odedara AB, Patel PA (2015) Evaluation of physiological and biochemical responses in different seasons in Surti buffaloes, Veterinary World 8(6): 727-731.

\begin{abstract}
Aim: This study was conducted to evaluate the impact of hot dry, hot humid and comfortable season on physiological, hematological, biochemical, and oxidative stress parameters in Surti buffaloes.

Materials and Methods: Ten lactating Surti buffaloes of similar physiological status were selected. Based on the temperature-humidity index (THI), their natural exposure to the environment was categorized as hot dry $\left(\mathrm{THI}_{1}\right)$, hot humid $\left(\mathrm{THI}_{2}\right)$ and moderate winter/comfort season $\left(\mathrm{THI}_{3}\right)$. Blood/serum samples were collected and analyzed for physiological, hematological, biochemical, and oxidative stress parameters. The results were analyzed using standard statistical methods.

Results: With increase in THI, significant rise in physiological parameters such as respiration rate (RR), hematological parameters such as red blood cell (RBC), hematocrit, hemoglobin $(\mathrm{Hb})$ and mean cell $\mathrm{Hb}$ concentration (MCHC), biochemical parameters such as alanine aminotransferase (ALT), Na, K, creatinine, blood urea nitrogen, $\mathrm{Mn}, \mathrm{Cu}$ and $\mathrm{Zn}$, hormones such as cortisol and oxidative stress parameters such as glutathione peroxidase (GPx), superoxide dismutase (SOD), lipid peroxide (LPO) and total antioxidant status (TAS) and significant decline in glucose, cholesterol and triiodothyronine ( $\mathrm{T}_{3}$ ) was observed.

Conclusion: It was concluded that THI is a sensitive indicator of heat stress and is impacted by ambient temperature more than the relative humidity in buffaloes. Higher THI is associated with significantly increased RR, total RBC count, $\mathrm{Hb}$, hematocrit, MCHC, ALT, urea, sodium, creatinine, triiodothyronine, SOD, GPx, LPO and TAS and with significant decrease in glucose, cholesterol and triiodothyronine $\left(\mathrm{T}_{3}\right)$.
\end{abstract}

Keywords: biochemical, heat stress, physiological, surti buffalo, temperature humidity index.

\section{Introduction}

The buffaloes are essentially shade and water loving animals and are well suited to hot and humid climate, but they exhibit signs of heat stress when exposed to direct solar radiation. This is due to the fact that buffalo's body absorbs a great deal of solar radiation because of their dark skin and sparse coat or hair, and in addition to that they possess a less efficient evaporative cooling system due to their rather poor sweating ability. Particularly, exposure of buffaloes to the latter conditions evokes a series of drastic changes in biological functions that include depression in feed intake, efficiency and utilization [1], disturbances in metabolism of water, protein, energy and mineral balances, enzymatic reactions, hormonal secretions and blood metabolites [2]. Such changes result in impairment of growth, production, and reproduction performance.

The effect of heat stress is aggravated when heat stress is accompanied by high ambient humidity.

Copyright: The authors. This article is an open access article licensed under the terms of the Creative Commons Attributin License (http:// creative commons.org/licenses/by/2.0) which permits unrestricted use, distribution and reproduction in any medium, provided the work is properly cited.
Temperature humidity indices (THI) are used to know the amount of heat stress in animals [3]. It takes into account the temperature and the humidity of the environment to which the animals are exposed.

Most of the studies in relation to heat stress have been done on exposure of buffaloes to direct solar radiation. However there are very few studies conducted on buffaloes related to microenvironment to which animals are confined. Therefore, the present study was conducted on Surti buffaloes in the microenvironment of three different seasons along with THI with the objective to find out the markers of heat stress.

\section{Materials and Methods}

\section{Ethical approval}

The experiment was part of NICRA project (ICAR-NDRI) and it followed the guidelines of Institutional Animal Ethics Committee.

\section{Animal selection}

This study was conducted on 10 lactating Surti buffaloes in same stage (4- $5^{\text {th }}$ lactation) of lactation maintained at Livestock Research Station, NAU, Navsari after successive natural exposure of the same 
animals to hot dry, hot humid and moderate winter (comfortable season). These animals were fed as per ICAR 1998 feeding standards.

\section{Meteorological observations}

Data of temperature and humidity of the shed in which animals were kept were recorded with the help of data logger for last 15 days. THI was calculated from mean temperature and mean relative humidity and using the formula of Mader et al. [4].

\section{Sample collection and analysis}

Blood sample in $\mathrm{K}_{3}$ ethylenediaminetetraacetic acid and serum collection tubes were carried out in hot dry $\left(\mathrm{THI}_{1}\right)$, hot humid $\left(\mathrm{THI}_{2}\right)$ and moderate winter/comfort season $\left(\mathrm{THI}_{3}\right)$. Blood samples were analyzed by hematology analyzer (Medonic CA620 VET - Boule Medical AB) for hematological parameters whereas the serum was separated by centrifugation at $3000 \mathrm{rpm}$ for $10 \mathrm{~min}$ and stored till analyzed. The serum was analyzed for total protein, cholesterol, glucose, chloride, calcium, magnesium, alanine aminotransferase (ALT) (U/L), AST (U/L), non-esterified fatty acid $(\mathrm{mmol} / \mathrm{L})$, creatinine $(\mathrm{mg} / \mathrm{dl})$ and blood urea nitrogen $(\mathrm{BUN})(\mathrm{mg} / \mathrm{dl})$ using "Randox" kits (Randox Laboratories Limited, United Kingdom). Triiodothyroxine $\left(\mathrm{T}_{3}\right)$, thyroxine $\left(\mathrm{T}_{4}\right)$ and cortisol were measured by standard enzyme-linked immunosorbent assay technique using assay kit (Labor Diagnostica Nord GmbH \& Co. KG, Nordhorn). Sodium and potassium were analyzed by systronic make 128 flame photometer. Iron-Fe ${ }^{+2}(\mathrm{ppm})$, manganese- $\mathrm{Mn}^{+2}$ $(\mathrm{ppm})$, copper-Cu $\mathrm{Cu}^{+2}(\mathrm{ppm})$ and zinc- $\mathrm{Zn}^{+2}(\mathrm{ppm})$ were analyzed on ECIL make atomic absorption spectrophotometer. Oxidative stress parameters viz. glutathione peroxidase (GPx) (UV method of Paglia and Valentine [5]), superoxide dismutase (SOD) [6] and lipid peroxides (LPO) in terms of malondialdehyde (MDA) production [7]. Red blood cell (RBC) hemolysate was used for analysis of oxidative stress parameters. Total antioxidant status (TAS) was estimated [8] using "Randox" kits (Randox Laboratories Limited, United Kingdom).

\section{Statistical analysis}

The data were subjected to analysis of variance [9] and the means were tested for significance by Duncan's multiple range test [10].

\section{Results}

The ambient temperature and relative humidity for hot dry $\left(\mathrm{THI}_{1}\right)$, hot humid $\left(\mathrm{THI}_{2}\right)$ and moderate winter/comfort season $\left(\mathrm{THI}_{3}\right)$ was $31.40^{\circ} \mathrm{C}, 60.30 \%$; $28.10^{\circ} \mathrm{C}, 85.60 \%$ and $22.10^{\circ} \mathrm{C}, 61.00 \%$ respectively. Based on this data results of THI calculated were as follows: $\mathrm{THI}_{1}=81.7$ for hot dry, $\mathrm{THI}_{2}=80.6$ for hot humid and $\mathrm{THI}_{3}=68.72$ for comfort season.

Marked increase in respiration rate (RR) occurred with the increase in THI. RBC, hematocrit, hemoglobin $(\mathrm{Hb})$ and mean cell $\mathrm{Hb}$ concentration (MCHC) increased significantly with an increase in
THI while the rest of the hematological parameters was found to be non-significant (Table-1). Table-2 shows the changes in biochemical parameters at three different THI. With the increase in THI, a significant increase in ALT, Na, K, creatinine, BUN and trace elements such as $\mathrm{Mn}, \mathrm{Cu}$ and $\mathrm{Zn}$ and a significant decrease in glucose and cholesterol was observed. Among the hormones studied there was a significant decrease in $\mathrm{T}_{3}$ with an increase in THI while the cortisol concentration significantly increased at $\mathrm{THI}_{1}$ as compared to $\mathrm{THI}_{3}$ (Table-2). Mean $\pm \mathrm{SE}$ values of the oxidative stress parameters are given in Table-3. The oxidative stress parameters viz. GPx, SOD, LPO and TAS increased significantly with an increase in THI.

\section{Discussion}

Even though relative humidity was very high in hot humid season $\left(\mathrm{THI}_{2}\right.$ ) as compared to that in hot dry season, the slight increase in ambient temperature during hot dry $\left(\mathrm{THI}_{1}\right)$ season has increased THI of hot dry season and it was slightly higher than that of hot humid $\left(\mathrm{THI}_{2}\right)$ season. Thus, it was deduced that as compared to the even major change in relative humidity, a minor change in ambient temperature causes more alteration in THI.

There was a significant increase in RR with an increase in ambient temperature $\left(\mathrm{THI}_{1}\right)$ and the relative humidity $\left(\mathrm{THI}_{2}\right)$ in hot dry season and hot humid season, respectively. Increase in RR indicates that the animals were in heat stress and animals enhance their RR to facilitate heat loss during heat stress and therefore it is recommended as a parameter to assess heat stress along with THI [11]. Scharf et al. [12] reported a significant daily increase of 15.4 breaths/min from 600 to $1300 \mathrm{~h}$ in Bos taurus during heat stress and Wankar et al. [13] have also noticed in adult buffaloes significantly increased $\mathrm{RR}$ at $35^{\circ} \mathrm{C}$ and $40^{\circ} \mathrm{C}$ as compared to $25^{\circ} \mathrm{C}$ and $30^{\circ} \mathrm{C}$. An increase in RR during afternoon as compared to morning as well as during summer (hot dry) as compared to hot humid season in growing and adult Sahiwal cattle have been reported by Chandrabhan et al. [14]. Non-significant difference in RT temperature may be due to increasing in RR, which may prevent the increase in rectal temperature in cows [15]. Non-significant difference in heart rate was observed in this study, which is in agreement with the findings of Singh and Bhattacharyya [16].

A significant increase in $\mathrm{RBC}, \mathrm{Hb}$, hematocrit (HCT) and MCHC was observed in hot dry as compared to the hot humid season. Increase in RBC (consequent to higher HCT) and $\mathrm{Hb}$ may be due to hemoconcentration in the hot dry season. Similar findings of increase in RBC at the beginning of the hot period has been reported by Koubkova et al. [17] and Omran et al. [18] and in summer season by Toharmat et al. [19]. Higher $\mathrm{MCH}$ and $\mathrm{MCHC}$ during summer have also been reported by Kumar and Pauchaura [20].

Significant decrease in glucose and cholesterol was observed in hot dry and hot humid 
Table-1: Physiological and hematological parameters (mean $\pm \mathrm{SE}$ ) in different seasons.

\begin{tabular}{|c|c|c|c|}
\hline Parameters & Hot dry $\left(\mathrm{THI}_{1}-81.7\right)$ & Hot humid $\left(\mathrm{THI}_{2}-80.6\right)$ & Comfort $\left(\mathrm{THI}_{3}-68.72\right)$ \\
\hline Rectal temperature $\left({ }^{\circ} \mathrm{F}\right)$ & $100.23 \pm 0.27$ & $100.19 \pm 0.19$ & $99.35 \pm 0.41$ \\
\hline RR (breaths/min) & $38.40 \pm 1.76 * *$ & $24.3 \pm 0.70 * *$ & $22.7 \pm 0.60 * *$ \\
\hline Heart rate (beats/min) & $70.2 \pm 1.53$ & $68.8 \pm 1.34$ & $69.3 \pm 1.81$ \\
\hline Total RBC count (millions/ $\mu \mathrm{l})$ & $7.03 \pm 0.33 * *$ & $5.99 \pm 0.24 * *$ & $5.22 \pm 0.47 * *$ \\
\hline $\operatorname{MCV}\left(\mu m^{3}\right)$ & $46.38 \pm 1.43$ & $46.8 \pm 1.17$ & $45.7 \pm 1.64$ \\
\hline HCT (\%) & $32.34 \pm 1.06 * *$ & $27.8 \pm 1.34 * *$ & $23.98 \pm 2.41 * *$ \\
\hline Total platelet count $\left(\times 10^{3} / \mu \mathrm{l}\right)$ & $248.2 \pm 16.61$ & $237.9 \pm 15.6$ & $220.6 \pm 10.96$ \\
\hline Total WBC count $\left(\times 10^{3} / \mu \mathrm{l}\right)$ & $15.28 \pm 1.72$ & $13.06 \pm 1.67$ & $15.16 \pm 1.62$ \\
\hline $\mathrm{Hb}(\mathrm{g} / \mathrm{dl})$ & $11.36 \pm 0.36 *$ & $10.29 \pm 0.48^{*}$ & $8.79 \pm 0.82 *$ \\
\hline $\mathrm{MCH}(\mathrm{pg})$ & $16.29 \pm 0.46$ & $17.21 \pm 0.45$ & $16.86 \pm 0.52$ \\
\hline $\mathrm{MCHC}(\mathrm{g} / \mathrm{dl})$ & $35.19 \pm 0.34 * *$ & $36.82 \pm 0.34 * *$ & $36.96 \pm 0.42 * *$ \\
\hline LYM (\%) & $49.7 \pm 4.40$ & $50.45 \pm 3.88$ & $43.38 \pm 4.93$ \\
\hline MID cell (\%) & $7.93 \pm 0.54$ & $8.2 \pm 0.67$ & $7.55 \pm 0.32$ \\
\hline GRAN (\%) & $42.37 \pm 4.10$ & $41.15 \pm 3.32$ & $49.07 \pm 4.71$ \\
\hline
\end{tabular}

*Significance at $\mathrm{p} \leq 0.05 ; * *$ Significance at $\mathrm{p} \leq 0.01, \mathrm{SE}=$ Standard deviation, $\mathrm{RR}=$ Respiration rate, WBC=White blood cell, $\mathrm{MCV}=$ Mean cell volume, $\mathrm{Hb}=$ Hemoglobin, $\mathrm{MCH}=$ Mean cell hemoglobin, $\mathrm{MCHC}=$ Mean cell hemoglobin concentration, LYM=Lymphocytes, MID=Midsized cell, GRAN=Granulocytes

Table-2: Biochemical parameters (mean \pm SE) in different seasons.

\begin{tabular}{|c|c|c|c|}
\hline Parameters & Hot dry $\left(\mathrm{THI}_{1}-81.7\right)$ & Hot humid $\left(\mathrm{THI}_{2}-80.6\right)$ & Comfort $\left(\mathrm{THI}_{3}-68.72\right)$ \\
\hline AST (U/L) & $119.9 \pm 4.03$ & $131 \pm 7.91$ & $121.12 \pm 5.51$ \\
\hline $\operatorname{ALT}(U / L)$ & $58.08 \pm 3.02 * *$ & $55.46 \pm 5.00 * *$ & $39.67 \pm 4.53 * *$ \\
\hline Total protein $(\mathrm{g} / \mathrm{dl})$ & $6.67 \pm 0.48$ & $7.24 \pm 0.19$ & $6.35 \pm 0.21$ \\
\hline Albumin $(\mathrm{g} / \mathrm{dl})$ & $3.78 \pm 0.10$ & $3.75 \pm 0.12$ & $4.11 \pm 0.16$ \\
\hline Cholesterol (mg/dl) & $103.4 \pm 10.72 * *$ & $75.5 \pm 8.50 * *$ & $118.6 \pm 11.75 * *$ \\
\hline Glucose $(\mathrm{mg} / \mathrm{dl})$ & $47.84 \pm 1.38^{* *}$ & $64.6 \pm 3.22 * *$ & $73.1 \pm 3.2 * *$ \\
\hline Sodium-Na (mmol/L) & $149.50 \pm 3.11 * *$ & $135.19 \pm 5.39 * *$ & $110.14 \pm 4.33 * *$ \\
\hline Potassium-K (mmol/L) & $5.25 \pm 0.14 * *$ & $5.616 \pm 0.47 * *$ & $3.82 \pm 0.26 * *$ \\
\hline Non esterified fatty acid (mmol/L) & $0.44 \pm 0.01$ & $0.607 \pm 0.24$ & $0.235 \pm 0.01$ \\
\hline Creatinine (mg/dl) & $2.43 \pm 0.18^{* *}$ & $0.42 \pm 0.03 * *$ & $1.61 \pm 0.10 * *$ \\
\hline BUN (mg/dl) & $35.00 \pm 0.70 * *$ & $27.99 \pm 0.43 * *$ & $14.8 \pm 0.88 * *$ \\
\hline Iron-Fe $\mathrm{Fe}^{+2}(\mathrm{ppm})$ & $1.40 \pm 0.07$ & $1.34 \pm 0.1$ & $1.30 \pm 0.04$ \\
\hline Manganese- $\mathrm{Mn}^{+2}(\mathrm{ppm})$ & $0.471 \pm 0.01 * *$ & $0.47 \pm 0.01 * *$ & $0.34 \pm 0.02 * *$ \\
\hline Copper-Cu+2 (ppm) & $0.111 \pm 0.01 * *$ & $0.115 \pm 0.01 * *$ & $0.214 \pm 0.01 * *$ \\
\hline Zinc-Zn+2 (ppm) & $0.90 \pm 0.13 *$ & $0.69 \pm 0.07 *$ & $0.53 \pm 0.04 *$ \\
\hline Triiodothyronine- $\mathrm{T}_{3}(\mathrm{ng} / \mathrm{ml})$ & $1.88 \pm 0.05^{*}$ & $1.79 \pm 0.06 *$ & $1.66 \pm 0.06 *$ \\
\hline Tetraiodothyroxine- $T_{4}(\mu \mathrm{g} / \mathrm{dl})$ & $4.76 \pm 0.20$ & $4.69 \pm 0.17$ & $4.90 \pm 0.27$ \\
\hline Cortisol ( $\mu \mathrm{g} / \mathrm{dl})$ & $1.82 \pm 0.10$ & $1.71 \pm 0.09$ & $1.55 \pm 0.10$ \\
\hline
\end{tabular}

*Significance at $\mathrm{p} \leq 0.05 ; * *$ Significance at $\mathrm{p} \leq 0.01, \mathrm{SE}=$ Standard deviation, AST=Aspartate aminotransferase,

$\mathrm{ALT}=$ Alanine aminotransferase, NEFA=Non esterified fatty acid, BUN=Blood urea nitrogen

Table-3: Oxidative stress parameters (mean \pm SE) in different seasons.

\begin{tabular}{|c|c|c|c|}
\hline Parameters & Hot dry $\left(\mathrm{THI}_{1}-\mathbf{8 1 . 7}\right)$ & Hot humid $\left(\mathrm{THI}_{2}-80.6\right)$ & Comfort $\left(\mathrm{THI}_{3}-68.72\right)$ \\
\hline $\mathrm{GPx}(\mathrm{U} / \mathrm{ml})$ & $97.24 \pm 4.31 * *$ & $70.97 \pm 3.47 * *$ & $43.42 \pm 6.17 * *$ \\
\hline LPO (nmol of MDA/ml of packed cells) & $4.83 \pm 0.33 * *$ & $3.57 \pm 0.13 * *$ & $3.16 \pm 0.32 * *$ \\
\hline $\operatorname{SOD}(U)$ & $6.40 \pm 0.20 * *$ & $3.72 \pm 0.18 * *$ & $3.36 \pm 0.43 * *$ \\
\hline TAS (mmol/L) & $5.28 \pm 0.06 * *$ & $2.92 \pm 0.14 * *$ & $2.01 \pm 0.10 * *$ \\
\hline
\end{tabular}

$*$ Significance at $\mathrm{p} \leq 0.05 ; * *$ Significance at $\mathrm{p} \leq 0.01, \mathrm{SE}=$ Standard deviation, GPx=Glutathione peroxidase, LPO $=$ Lipid peroxide, $\mathrm{SOD}=$ Superoxide dismutase, $\mathrm{TAS}=$ Total antioxidant status

season as compared to comfortable season. Decrease in glucose $[17,21]$ and cholesterol $[12,15]$ may be due to decrease in feed intake. While a significant increase in ALT and urea was observed in hot dry season. Increase in ALT in hot period is in agreement with the findings of Koubkova et al. [17], Chandrabhan et al. [14] and Singh and Bhattacharyya [16]. The increase in ALT may be due to increase in gluconeogenesis $[17,22]$ or due to some deleterious effect of heat stress on liver activity [23-25]. Increase in urea in the hot dry and hot humid season may be due to catabolism of protein to maintain the metabolic needs of the body. Increase in urea is also an indication of dehydration as reported by Scharf et al. [12]. Increase in urea in summer or the hot period has been reported by Koubkova et al. [17] and Das et al. [26].

Increase in sodium concentration may be due to dehydration. However, it also depends on the amount of water intake which was not measured in the present study and animals had ad libitum access to water. The rate of excretion of creatinine is influenced by renal perfusion and glomerular filtration 
rate. A reduction in blood flow to the kidneys during heat stress may increase the creatinine concentration. Ronchi et al. [27,28] recorded decrease in glucose as well as an increase in urea and creatinine as a result of muscular catabolism for energy supply.

In the present study significant increase in $\mathrm{T}_{3}$ but non-significant decrease in $\mathrm{T}_{4}$ in hot dry period as compared to hot humid period was observed. Decrease in thyroid hormones occurs during heat acclimation and those mammals acclimated to warmer climate adopt this pattern $[29,30]$.

A significant increase in SOD, GPx, LPO and TAS was observed which indicates increased production of the free radical in hot dry, as well as hot humid season. However, the values of the antioxidant parameters in the hot dry season was significantly higher than the hot humid season indicating that hot dry season is more stressful to Surti buffaloes and leads to increased production of free radicals. Higher levels of SOD and GPx in summer season in Murrah buffalo calves, heifers and lactating buffaloes have been reported by Lallawmkimi [31]. LPO in the form of MDA production was found to be higher in the summer season. Thiobarbituric acid reactive substances is also an indicator of LPO which was also found to increase in summer season in cows as observed by Bernabucci et al. [30] and also on exposure of animals to sun as compared to animals kept in shade [32]. Quantification of single antioxidant status tells us little about the whole body defense and a number of antioxidants need to be estimated. Therefore, nowadays TAS or total antioxidant status is measured [33]. In the present study the TAS significantly increased in hot dry season but to come to a concluding point still research needs to be conducted.

\section{Conclusion}

From the present study, it can be concluded that THI is a sensitive indicator of heat stress and is impacted by ambient temperature more than the relative humidity in buffaloes. Higher THI is associated with significantly increased $\mathrm{RR}$, total $\mathrm{RBC}$ count, $\mathrm{Hb}$, HCT, MCHC, ALT, urea, sodium, creatinine, triiodothyronine, SOD, GPx, LPO and TAS and with significant decrease in glucose and cholesterol. These effects may be direct or indirect by altered feeding pattern, dehydration, etc. which necessitates further studies to ascertain precisely.

\section{Authors' Contributions}

SSC planned and executed the experiment and prepared the manuscript. RCU was PI of NICRA project (ICAR) and guided for the study. VKS helped in the preparation of the manuscript and along with PAP and $\mathrm{ABO}$ conducted blood biochemical analysis. GP helped in blood collection and recording of physiological parameters All authors read and approved the final manuscript.

\section{Acknowledgments}

The authors are thankful to NDRI, Karnal for providing the grant under National Initiative on Climate Resilient Agriculture for carrying out the work. The authors are also thankful to Dean, Vanbandhu College of Veterinary Science and Animal Husbandry, Navsari Agricultural University for providing the necessary facilities.

\section{Competing Interests}

The authors declare that they have no competing interests.

\section{References}

1. Kumar, B.V.S., Kumar, A. and Kataria, M. (2011) Effect of heat stress in tropical livestock and different strategies for its amelioration. J. Stress Physiol. Biochem., 7(1): 45-54.

2. Ganaie, A.H., Shanker, G., Bumla, N.A., Ghasura, R.S., Mir, N.A., Wani, S.A. and Dudhatra, G.B.(2013)Biochemical and physiological changes during thermal stress in bovines. J. Vet. Sci. Technol., 4(126): 126-132.

3. Renaudeau, D., Collin, A., Yahav, S., De Basilio, V., Gourdine, J.L. and Collier, R.J. (2012) Adaptation to hot climate and strategies to alleviate heat stress in livestock production. Animal, 6(05): 707-728.

4. Mader, T.L., Davis, M.S. and Brown-Brand, T. (2006) Environmental factors influencing heat stress in feedlot cattle. J. Anim. Sci., 84: 712-719.

5. Paglia, D.E. and Valentine, W.N. (1967) Studies on the quantitative and qualitative characterization of erythrocyte glutathione peroxidase. J. Lab. Clin. Med., 70: 158-159.

6. Madesh, M. and Balasubramanian, K.A. (1998) Microtitre plate assay for superoxidase dismutase using MTT reduction by superoxide. Indian J. Biochem. Biophys., 35: 184-188.

7. Rehman, S.U. (1984) Lead induced regional lipid peroxidation in brain. Toxicol. Lett., 21: 333-337.

8. Miller, N.J., Rice-Evans, C. and Davies, M.J. (1993) A new method for measuring antioxidant activity. Biochem. Soc. Trans., 21: 95 .

9. Snedecor, G.W. and Cochran, W.G. (1980) Statistical Methods. $7^{\text {th }}$ ed. Iowa State University Press, Ames, Iowa, USA. p593.

10. Duncan, D.B. (1955) Multiple range and multiple 'F test'. Biometrics, 11: 1-42.

11. Perez, J.H. (2000) Parameters for the determination and evaluation of heat stress in dairy cattle in South Africa. J. Vet. Res., 67: 263-271.

12. Scharf, B., Carrol, J.A., Riley, D.G., Chase, C.C., Jr. Coleman, S.W., Keilser, D.H., Werber, D.E. and Spiers, D.E. (2010) Evaluation of physical and blood serum differences in heat tolerant (Romosinuano) and heat susceptible (Angus) Bos taurus cattle during controlled heat challenge. J. Anim. Sci., 88: 2321-2336.

13. Wankar, A.K., Singh, G. and Yadav, B. (2014) Thermoregulatory and adaptive responses of adult buffaloes (Bubalus bubalis) during hyperthermia: Physiological, behavioral, and metabolic approach. Vet. World, 7(10): 825-830.

14. Chandrabhan, Singh, S.V., Hooda, O.K., Upadhyay, R.C., Baliyan Beenam and Vaidya, M. (2012). Influence of temperature variability on physiological, hematological and biochemical profile of growing and adult Sahiwal cattle. $J$. Environ. Res. Dev., 7: 986-994.

15. Gudev, D., Popova-Ralcheva, S., Moneva, P., Aleksiev, Y., Peeva, T., Penchev P. and Ilieva, I. (2007) Physiological indices in buffaloes exposed to sun. Arch. Zootech., 10: 127-133.

16. Singh, K. and Bhattacharyya, N.K.(1990) Cardio-respiratory 
activity in Zebu and their F1 crosses with European breeds of dairy cattle at different ambient temperatures. Livest. Prod. Sci., 24: 119-128.

17. Koubkova, M., Knizkova, I., Kunc, P., Hartlova, H., Flusser, J. and Dolezal, O. (2002) Influence of high environmental temperatures and evaporative cooling on some physiological, haematological and biochemical parameters in high-yielding dairy cows. Czech J. Anim. Sci., 47: 309-318.

18. Omran, F.I., Ashour, G.H., Hassan, L.R., Shafie, M.M. and Youssef, M.M. (2011a) Physiological responses and growth performance of buffalo and Friesian calves under chronic severe heat stress. In: Proceedings of the $4^{\text {th }}$ Scientific Conference of Animal Wealth Research in the Middle East and North Africa, Foreign Agricultural Relations (FAR), Egypt. Massive Conferences and Trade Fairs. p1-13.

19. Toharmat, T., Nonaka, I., Shimizu, M., Batajoo, K.K. and Kume, S. (1998) Effects of prepartum energy intake and calving season on blood composition of periparturient cows. Asian-Aust. J. Anim. Sci., 11(6): 739.

20. Kumar, B. and Pauchaura, S.P. (2000) Haematological profile of crossbred dairy cattle to monitor herd health status at medium elevation in central Himalayas. Res. Vet. Sci., 69: 141-145.

21. Omran, F.I., Ashour, G., Youssef, M.M. and Shafie M.M. (2011b) Responses of hematology, blood metabolites, mineral ions and hormonal profile to heat stress for Egyptian buffalo-calves. Egypt. J. Agric. Res., 89(3): 1129-1138.

22. Cincovic, M.R., Belic, B., Toholj, B., Potkonjak, A., Stevancevic, M., Lako, B. and Radovic, I. (2013) Metabolic acclimation to heat stress in farm housed holstein cows with different body condition scores. Afr. J. Biotechnol., 10(50): 10293-10303.

23. Marai, I.F.M., Daader, A.M., Abdel-Samee, A.M. and Ibrahim, H. (1997a) Winter and summer effects and their amelioration on lactating Friesian and Holstein cows maintained under Egyptian conditions. In: Proceedings of the International Conference on Animal, Poultry, Rabbits and Fish Production and Health, Cairo, Egypt.

24. Marai, I.F.M., Daader, A.M., Abdel-Samee, A.M. and Ibrahim, H. (1997b) Lactating Friesian and Holstein cows as affected by heat stress and combination of amelioration techniques under Egyptian conditions. In: Proceedings of the International Conference on Animal, Poultry, Rabbits and Fish Production and Health, Cairo, Egypt.

25. Marai, I.F.M., Habeeb, A.A.M., Daader, A.H. and Yousef, H.M. (1997c) Effects of diet supplementation and body cooling on Friesian calves reared in high ambient temperature in the Eastern Desert of Egypt. Trop. Anim. Health Prod., 4: 201-208.

26. Das, K., Singh, J., Singh, G. and Nayan, V. (2013) Effect of heat stress alleviation on plasma protein, metabolites and lipid profile in lactating Nili-Ravi buffaloes under tropical climate. Indian J. Anim. Sci., 83(5): 86-89.

27. Ronchi, B., Bernabucci, U., Lacetera, N., Verini, S.A. and Nardone, A. (1999) Distinct and common effects of heat stress and restricted feeding on metabolic status in Holstein heifers. Zootec. Nutr. Anim., 25: 71-80.

28. Ronchi, B., Bernabucci, U., Lacetera, N.G., Nardone, A. and Bertoni, G. (1997) Effects of heat stress on metabolic-nutrition status of Hostein cows. Zootec. Nutr. Anim., 21: 209-221.

29. Horowitz, M. (2001) Heat acclimation: Phenotypic plasticity and cues to the underlying molecular mechanisms. $J$. Therm. Biol., 26: 357-363.

30. Bernabucci, U., Ronchi, B., Lacetera, N. and Nardone, A. (2002) Markers of oxidative status in plasma and erythrocytes of transition dairy cows during hot season. J. Dairy Sci., 85: 2173-2179.

31. Lallawmkimi, C.M. (2009) Impact of thermal stress and vitamin-E supplementation on Heat shock protein 72 and antioxidant enzymes in Murrah buffaloes. Ph. D. Thesis National Dairy Research Institute (deemed University), Karnal, India.

32. Aengwanich, W., Kongbuntad, W. and Boonsorn, T. (2011) Effects of shade on physiological changes, oxidative stress, and total antioxidant power in Thai Brahman cattle. Int. J. Biometeorol., 55: 741-748.

33. Celi, P. (2011) Biomarkers of oxidative stress in ruminant medicine. Immunopharmacol Immunotoxicol., 33(2): $233-240$. 